\title{
閉鎖性水域の風波発生下での乱れ構造 及びバーストの周期について \\ TURBULENT STRACTURE AND BURSTING PERIOD IN WIND/WATER WAVES IN CLOSED BASIN
}

\author{
禢津家久 ${ }^{1} \cdot$ 牛島省 $^{2} \cdot$ 井上理恵 $^{3}$ \\ Iehisa NEZU, Satoru USHIJIMA and Rie INOUE \\ 1フェロー 工博 京都大学大学院教授 環境地球工学専攻 (テ606-8501 京都市左京区吉田本町) \\ 2正会貝 工博 京都大学大学院助教授 環境地球工学専攻 \\ 学生会員 京都大学大学院 環境地球工学専攻
}

\begin{abstract}
Downward-bursting phenomena in water beneath wind waves is important in the process of the momentum, heat and mass transfer across the air-water interface. The coherent structure is closely related to the wind-waves in specially DBBL (downward-bursting boundary layer, about 3-7 times depth of the significant wave height). The turbulent intensities and Reynolds stress (-uv) in closed wind water waves could be expressed by the parameters of wind-waves, the intensity of water depth fluctuation and the peak frequency.

To estimate the bursting period, the u-v quadrant threshold technique is applied to the streamwise velocity signals in the water flows. The bursting period is in a good agreement with the behavior of time series of Reynolds stress (-uv). As a result, it became clear that the bursting period has a close connection with the peak frequency of wind-waves.
\end{abstract}

Key Words : wind-water waves, significant wave height, peak frequency, bursting period

\section{1.はじめに}

現在, 各種気体の地球環境内での循環過程の評価 が重要な課題となっている。その際，水域環境にお ける水/空気界面での気体の輸送量の定量的評価が必 要となるが, 依然として未解明な点が多く, 界面近 傍での組織構造を明らかにする必要がある。しか し，風波は位相によって風の応力分布が異なり，ま たその応力に由来する水側の局所的なせん断流によ る乱れ，砕波などは非線形性が強い現象である。

Okuda ${ }^{1), 2), 3)}$ は, 一連の研究からクレスト直下から風 上側にかけて流速が非常に速く，渦度も大きい領域 が伸びていることを明らかにした。この領域は気流 の再付着点に当たる部分で，気流から運動量を受け 取り，水中の乱流場にその運動量を輸送する役割を 果たしていると考えられる。また，瞬間の渦度分布 図によって，この領域で非定常的に正負の渦度がま とまって分布していることを示している. 同様の瞬
間構造が，鿅津. 中山 ${ }^{4}$ によっても指摘されている。 この渦度分布は，表層の高渦度領域が間欠的に下方 へ取り込まれて形成されると考えられる。

そこで, Yoshikawa et al. ${ }^{5)}$ さうした水面下での秩 序運動を明らかにするために温度変動と流速変動の 同時計測を行っている．水槽に温度成層がないとい う条件下で，温度を表層で冷やされた水塊に対する トレーサーとして用いている。この実験より，低温 の水塊が間欠的に下層へと進入する現象が明らかに なった。このとき流速の主流方向は成分は正, 鉛直 方向は負の下降流を示しており，この現象が運動量 の下向きの輸送に大きく寄与していることがわかっ た。こうした組織構造は，運動量だけでなく気体な どの物質交換においても注目されている.

そこで，本研究では水路の上下流端を閉めきり反 流がある流れを対象として，まず乱れ構造と風波の 関係を明らかにする。そして，気体輸送過程の予測 に㧍いて重要である界面から下方へのバースティン 
グ周期を風波の特性から推定することを試みたもの である。

\section{2. 従来の研究}

Toba ${ }^{6)}$ は界面近傍での様々な実験・観測デー夕の検 討から, 風波の直下の風波と直結した特別な乱流境 界層 (深さは有義波高 $H_{s}$ の3 - 7 倍 (約 5倍))の存在を 明らかにした。Toba ${ }^{6}$ は方バースティング境界層 (Downward-Bursting Boundary Layer, DBBL) と呼んで おり，風波上の気流側の乱流境界層にみられる秩序 運動によく対応している。この層の特徴は, 通常の 壁法則から推定したよりも高い渦拡散の值を有する ことである.この等方性乱流の領域は約 $5 H_{s}$ で, 波龄 の若い風洞水槽の実験結果から, 海洋での実測結果 まで幅広く成立している，風波発生下の乱流構造が 有義波高 $H_{s}$ によって無次元化できる (DBBLと有義波 高 $H_{s}$ の比が一定となる) のは，1）風波下での秩序運 動の始まりは, 局所的な吹送流の浸透であるためそ のエネルギーは水表面由来であること，2）風波の波 形は鉿直万向に $H_{s}$ の幅で制限されていることが理由 として挙げられている.

風波発生下での乱れ強度を水面変動強度 $\eta^{\prime}$ と風波 のピーク周波数 $f_{p}$ で無次元化すると乱れ強度とレイノ ルズ応力がそれぞれ1つの線にまとまってくることが Yoshikawa et al. ${ }^{5}$ によって示されている.このこと は, 風波の砕波調節(Toba ${ }^{7)}$ )として物理的に説明され ている. 以上のことから, 風波と水中の乱流とが密 接な関係を保ちながら発達していることが解る。

また，界面を通しての物質輸送に関してKomori et al. ${ }^{8)}$ は気液界面に働くせん断力の有無に関わらず，界 面近傍で発生する大規模渦に支配されているとして いる。そして，これまではモデル的概念であった表 面更新率 $r(1 / \mathrm{sec})$ (Danckwerts $\left.{ }^{9}\right)$ を直接表面更新渦の 発生周波数 $f$ によって評価している.

$$
K_{L}=0.34 \sqrt{D_{L F} f_{s}}
$$

ここに， $D_{L F}$ は気体の分子拡散係数である．この組 織構造の発生数波数 $f_{s}$ はVITA法によって水・空気の 両層で求められている。 $U_{* a}<0.25(\mathrm{~m} / \mathrm{sec}) て ゙ は U_{* a}$ の3

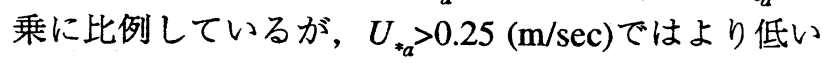
増加率となるため， $f_{s}$ は $U_{*_{a}}$ のみの関数で表すことは できない。その原因は，風波でのこの傾向がRashidi and Banerjee ${ }^{10)}$, Rashidi et al. ${ }^{11)}$ の開水路の值と一致 しないことから，水面に波が発生するとエネルギー 輸送の形態が変わるためではないかと考えられてい る. そのためKomori et al. ${ }^{8}$ は波長 $\lambda$ と空気一様流速 $U_{\infty}$ を用いたレイノルズ数に対して, 同様のパラメー
表-1 実験条件

\begin{tabular}{|c||c|c|c|c|c|}
\hline case & $\begin{array}{c}H \\
(\mathrm{~cm})\end{array}$ & $\begin{array}{c}U_{a, \max } \\
(\mathrm{m} / \mathrm{s})\end{array}$ & $\begin{array}{c}U *_{a} \\
(\mathrm{~cm} / \mathrm{s})\end{array}$ & $\begin{array}{c}\eta^{\prime} \\
(\mathrm{cm})\end{array}$ & $\begin{array}{c}\lambda \\
(\mathrm{cm})\end{array}$ \\
\hline wa & 20.0 & 2.59 & 10.98 & 0.03 & - \\
\hline wb & 20.0 & 4.24 & 18.33 & 0.12 & 9.11 \\
\hline wc & 20.0 & 9.06 & 52.20 & 0.83 & 29.22 \\
\hline wd & 20.0 & 11.60 & 95.17 & 1.20 & 41.85 \\
\hline
\end{tabular}

夕で無次元化した周波数 $f_{s}$ を示しているが, その関 係は明らかになってはいない。

そこで本研究では, 界面近傍での組織構造の周期 と風波のパラメータとの相関をより明らかにするこ とを目的とする。

\section{3. 実験装置及び実験方法}

本実験は, 全長 $16 \mathrm{~m}$, 幅 $40 \mathrm{~cm}$, 高さ $50 \mathrm{~cm}$ の風洞付 き水路を用いて行った。 座標系は流下方向を $x$, 界面 から下向きに $y^{\prime}$ ( $y^{\prime}=H-y, H$ は水深), 界面から上向き にzとした，流速変動成分は流下方向成分を $u(t)$ ，鉛 直方向成を $v(t)$ とした.

瞬間流速の測定には, $300 \mathrm{~mW} 4$ ビーム後方散乱型 2成分レーザ流速計 (Dantec社製)を用いて，流れの十 分に発達した水路上流端から約 $9 \mathrm{~m}$ の地点で水側及び 空気側の水路中央断面における計測を行った．LDA のトラバース装置は水路に直付けで $1 / 100 \mathrm{~mm}$ の精度 を持つ. 水流の計測については, 計測時間 60-90 $\mathrm{sec}$, 測定周波数は約 $150 \mathrm{~Hz}$ で行った。 その際に, 計 測部の鉛直上方に分解能が $0.1 \mathrm{~mm}$ の超音波波高計 (Keyence社製) を設置して流速変動と水面変動の同時 計測を行った。一方, 空気流の計測の際には計測を 高精度に行うためにシーディング発生装置を用い，1 点でのサンプル数を1万個に固定して計測を行った。 測定周波数は界面から十分離れた位置で約 $1 \mathrm{kHz}$ あった。ささらに，風波の波長 $\lambda$, 及び有義波高 $H_{s}$ の測 定には，デジタルカメラによって水路の側壁より水 面を撮影し，得られた画像を用いて，最低30サンプ ル以上で平均化を行った

表-1に実験条件を示す，Hは水染， $U_{a \text { max }}$ は空気層 での最大風速， $U_{*}$ は空気層での風速分布に対数則を 適用して求めた摩擦速度, $\eta^{\prime}$ は水面変動強度, $\lambda$ は波 長である。

水路の上流端と下流端を仕切った静水上に風を吹 かせ, 反流あり(水層は静止条件：断面平均流速がゼ 口)の状態で実験を行った。風速は水面形状が滑面 (wa), 三次元的なさざ波(wb), 二次元的な重力波 (wc), 砕波 (wd) となるように変化させた。 

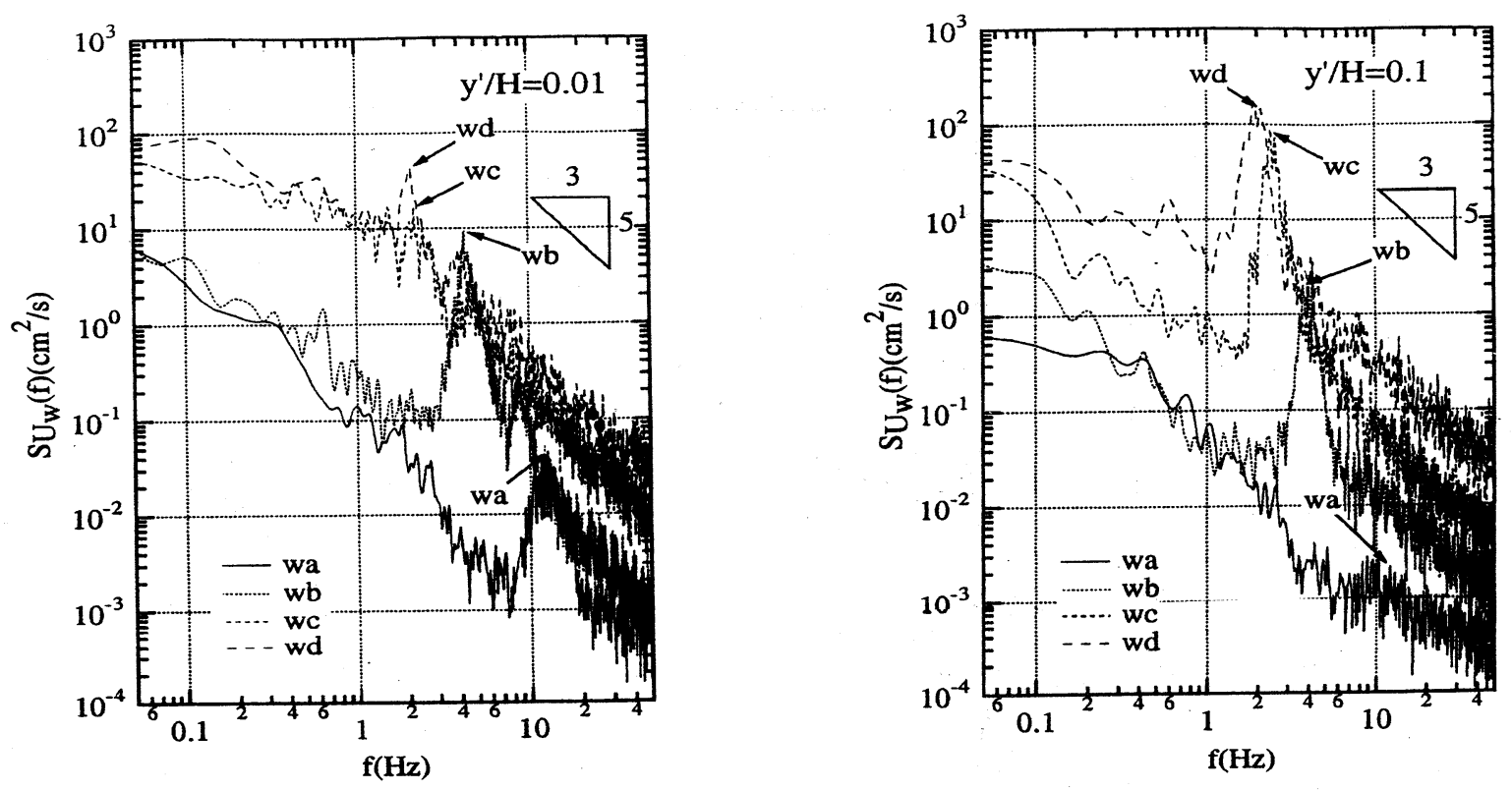

図-1＼cjkstart主流方向流速变動の周波数スペクトル $S_{u}(f)$

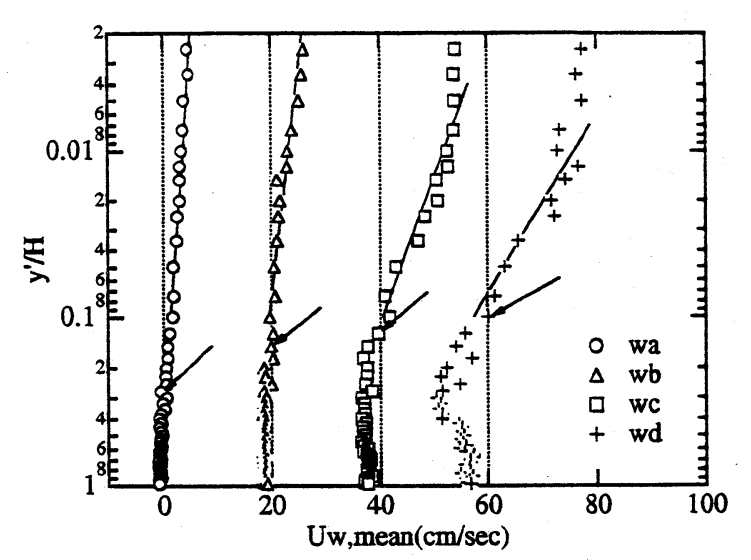

図-2 水側の主流速分布

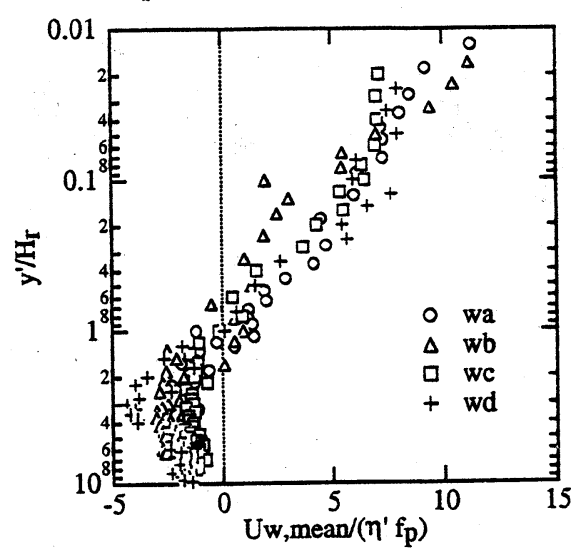

図-3 反流位置で基準化した水側の主流速分布

\section{4. 結果と考察}

\section{(1)平均流特性}

\section{a)周波数スペクトルの発達特性}

図-1は $y^{\prime} / H=0.01,0.1$ での主流方向流速変動 $u(t)$ の周 波数スペクトル $S_{u}(f)$ である. 風速が強くなるにつれ てスペクトルエネルギーが増大していくこと, 風波 の軌道運動に対応したピーク $f_{p}$ が低周波側に移行して いくことがわかる。このピーク周波数 $f_{p}$ はそれぞれの 風波の代表波の周期と一致している。また，その ピークの両端には-5/3乗則に対応する領域が存在して いる。一方, 界面からの距離が大きくなると水面が

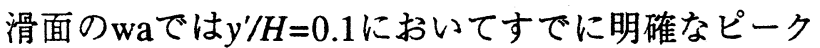
がなくなっている，逆に，二次元的重力波が発生し ているwcやwdでは $y^{\prime} / H=0.01 よ り も y^{\prime} / H=0.1$ において

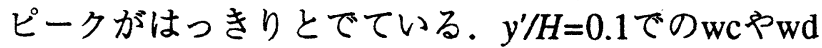
の傾向は，水面近傍での高渦度領域に対応している ためであると考えられる，以上から，風波の秩序運 動に沿う領域が波高に上って異なるこレがわかる。

\section{b)平均主流速}

図-2に界面から水側への主流速分布を示した。図 上に示した矢印は反流が発生した点である，風速が 強くなるにつれて, 反流点が水面に近付いてくるこ とがわかる．これは，風速が強くなるとともに反流 が活発化するためだと考えられる。また，界面近傍 以下の領域で対数則が成立しており，固体平板上の 乱流境界層に類似した秩序運動があることがわか る. しかし, 風波が発達してくると境界面は非常に 非線形性が高くなるため, 風速が増加するにつれて 水面近傍での対数則に沿わない領域が大きくなって いっている。これは, 固体平板上とは異なり, 気流 と密接に結びついて波の位相方向に分布を持つ接線 応力によって, 気流から運動量を受け取る構造が存 在するためであると考えられる。

図-3に図-2の水深方向を反流深さ $H_{r}$, 主流速を風波 のパラメータ (水面変動強度 $\eta^{\prime}$ と風波のピーク周波数 $\left.f_{p}\right)$ を用いて無次元化した結果を示した. 反流を伴う 風波の主流速分布が反流点を基準に自己相似性を 持っていることがわかる. 


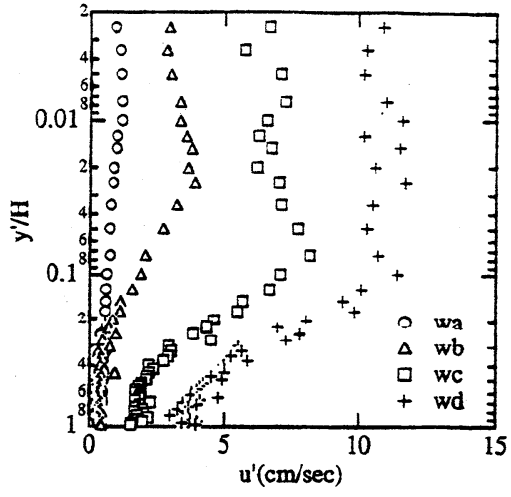

図-4 乱れ強度

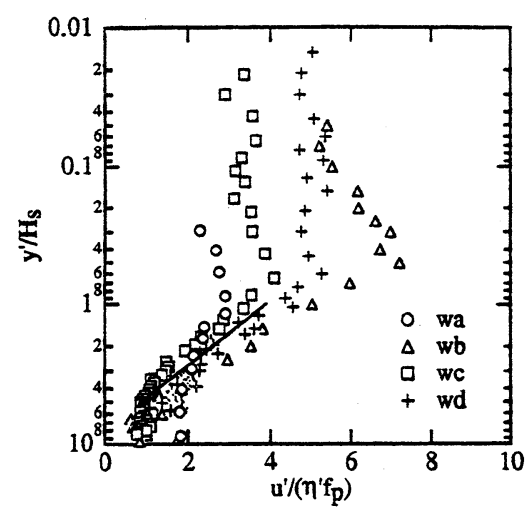

図-5 乱れ強度の風波パラメータによる無次元化

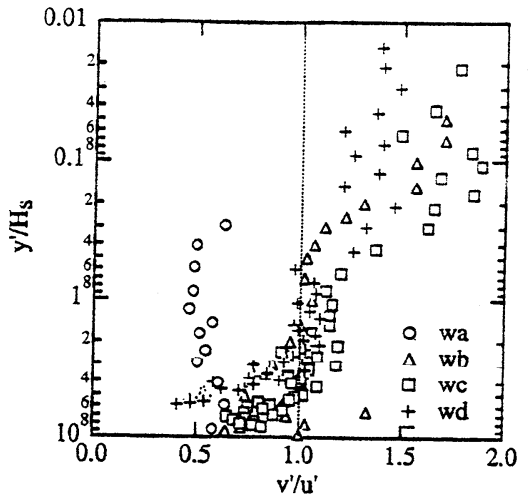

図-6 乱れ強度比

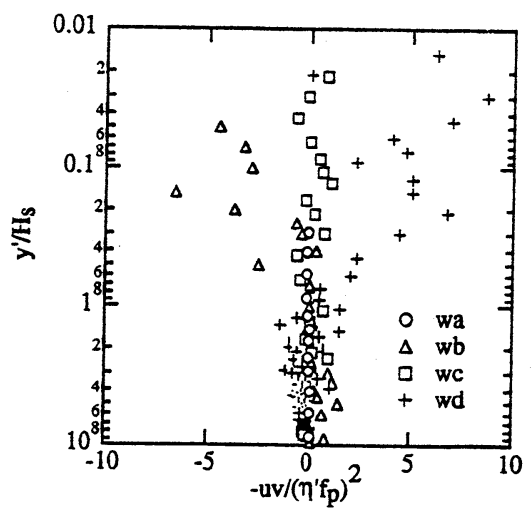

図-7 レイノルズ応力

\section{c)乱れ構造}

図-4は乱れ強度 $u^{\prime}, v^{\prime}$ の分布である，乱れ強度は風 が強くなるとともに大きくなり，深くまで及んでい る。また, 風波が発達するにつれて水面近傍では， 主流速方向よりも鉛直方向の乱れ強度がより強いこ とがわかる。

図-5は図-4の水泳方向を有義波高 $H_{s}$ で, 乱れ強度 を図-3と同様な風波のパラメー夕を用いて無次元化 した結果である，waでは可視化によっては明確な波 高, 波長が認められなかったため, 水面変動強度の 5倍の值を有義波高の值とした6)。この無次元化に よって, Yoshikawa et al. ${ }^{\text {5) }}$ と同様に異なる風速のデー 夕が一意的な関係として表示されることがわかる. この層 (DBBL, downward-bursting boudary layer ${ }^{6)}$ ) の 深さは有義波高の約3-7倍で, Toba ${ }^{6}$ の主張する值と 一致した。しかし，水面がほほ滑面であったwaの ケースでは，ずれがみられる。したがって，この無 次元化が特に水面上に波が発生した際に有効である ことが推察される。

図-6は乱れ強度比 $v^{\prime} / u^{\prime}$ の分布である．水面近傍にお いて波が発生しているケースでは $v^{\prime} / u^{\prime}>1.0$ ，滑面の ケース (wa)ではv'/u'>1.0である。この結果から，フ ルード数の小さい開水路流れで水面が稳やかな条件 に扔ける自由水面近傍での $v^{\prime}$ の低減効果 (Hunt and Graham $\left.{ }^{12}\right)$ とは反対に, 風波が発生すると $v^{\prime}$ の増幅効
果があることがわかる．また，DBBL (有義波高の約 3-7倍)ではほほ1.0の値をとっており，この領域で乱 れの等方性が成り立っていることが確認できた。

図-7はレイノルズ応力を上記の風波のパラメータ によって無次元化した結果である．水面近傍ではば らつきがあるが，これは水面の形状と関係があるの ではないかと考えられる．乱れ強度と同様にDBBL（ 有義波高の約3-7倍) で一意的な関係にまとまってく る傾向が認められた。

図-5, 6,7より，反流位置とDBBLの関係を考察す る. 水梁方向軸上での反流位置 $H_{r} / H_{s}$ はwaから順に, 33.0, 3.0, 1.1, 0.6である. この結果より, 平均主流速 の値の正負に関わらす，DBBLが成立していることが わかる.

\section{(2)組織構造}

図-8に界面近傍での気体輸送に寄与する組織構造

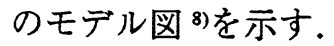

図-9はDBBLの範囲である $y^{\prime} / H_{s}=3.0$ でのレイノルズ 応力の時系列である．風が強くなるにつれて絶対值 が大きくなっている．また，間欠的に負の大きな値 をとり，その周期は風が強くなるにつれて短くなる ことがわかる。この現象が気相から液相への運動量 及び気体等の輸送に大きく寄与していると考えられ る。 


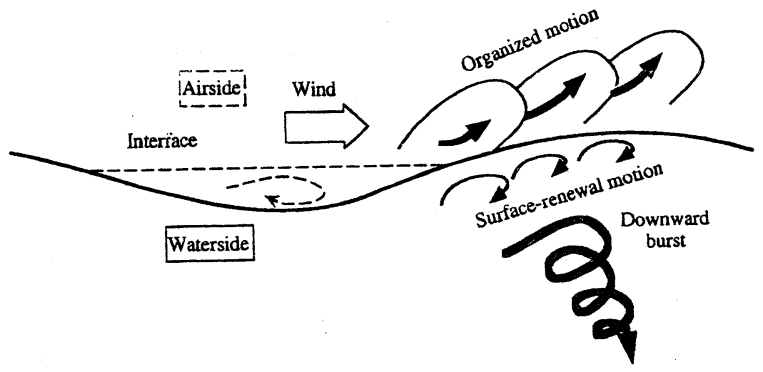

図-8 界面近傍での組織構造のモデル図

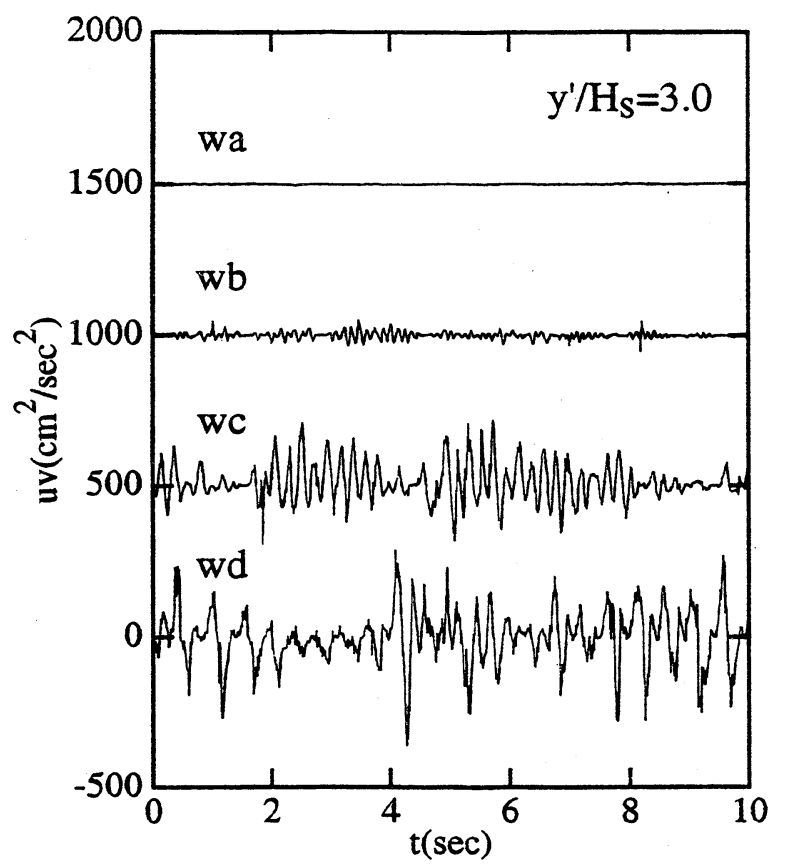

図-9 レイノルズ応力の時系列

本研究では図-9で確認された周期的な組織構造の 定量化を扔こなった，その手法として4像限区分しき い値法による条件付きサンプリングを用いた。レイ ノルズ応力に対する時間占有率 $T_{i}(H)$, 及び寄与率 $R S_{i}(H)$ はそれぞれ次式で定義される。

$$
\begin{aligned}
T_{i}(H) & = \begin{cases}\int_{H}^{\infty} p_{i}(w) d w, & (i=2,4) \\
\int_{-\infty}^{H} p_{i}(w) d w, & (i=1,3)\end{cases} \\
R S_{i}(H) & = \begin{cases}\int_{H}^{\infty} w \cdot p_{i}(w) d w>0, & (i=2,4) \\
\int_{-\infty}^{H} w \cdot p_{i}(w) d w<0, & (i=1,3)\end{cases}
\end{aligned}
$$

ここで, $p_{i}(w)$ は $w=u \cdot v$ の確率密度関数であり, $H$ はレイノルズ応力への各象限の寄与率のしきい值で ある。この手法によって任意のhole值に対する奇与率 の分布を算出し, hole值 $H=0$ における寄与率の半值に 対応するhole值をしきい值と定義する (Nezu and
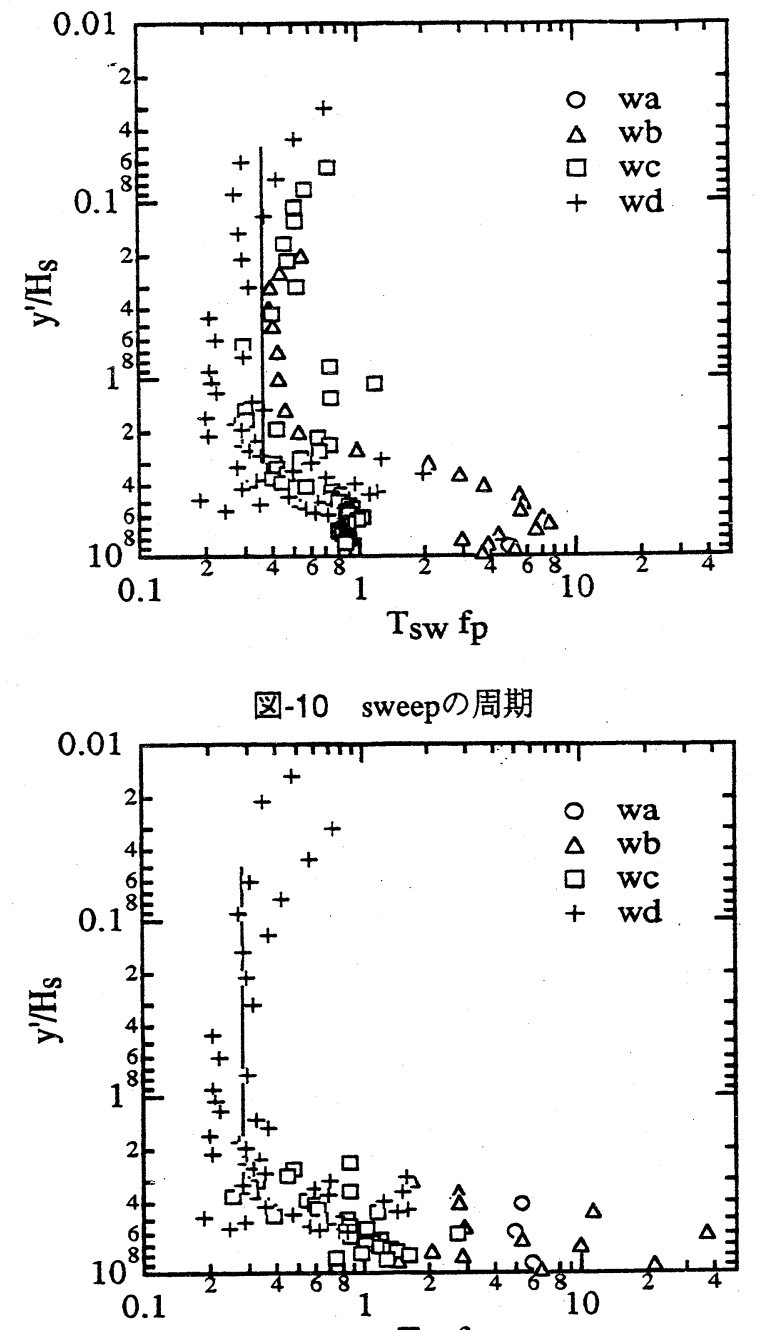

$T_{e j} f_{p}$

図-11 ejectionの周期

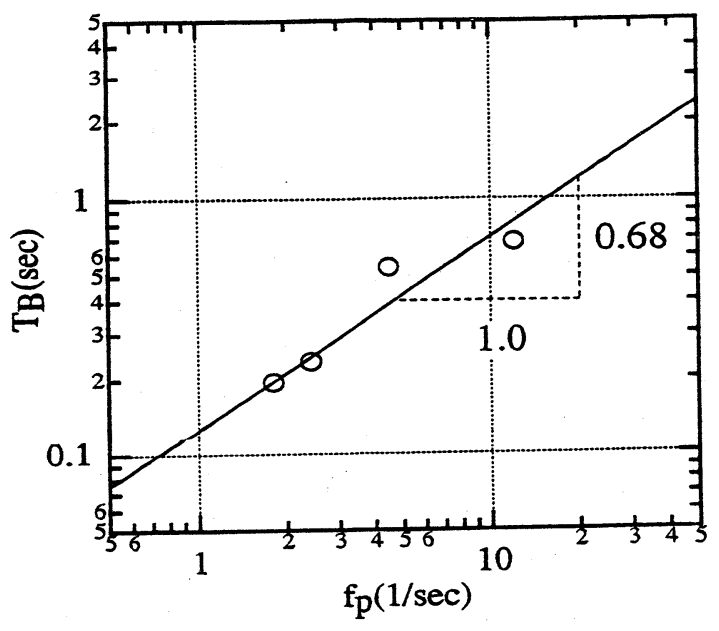

図-12 バースト周期

Nakagawa $\left.{ }^{13)}\right)$.この結果をもとに，しきい値を越える 寄与率に相当する現象を一回のバーストとしてカウ ントした。バーストの発生周期は，計測時間を得ら れたバーストの個数で割ることにより算出される.

図-10,11にこうして求めたsweep, ejectionの周期 の水深方向分布をそれぞれ風波のピーク周波数 $f_{p}$ で 無次元化して示した.4風速の值がほほ一つの線に まとまっている，図より水面近傍では一定值をと 
り，徐々に底面に向かって周期が長くなっていくこ とがわかる。この周期が長くなる傾向は，風が弱い ほど顕著である。また，底面に近づくと再び周期が 短くなっているが, これは底面近傍での組織構造の 影響であると考えられる。

以上のことから風波の組織構造は風波のピーク周 波数 $f_{p}$ と密接な関係があることがわかったので, 図12にDBBLでのバースト平均周期 $T_{B}$ を風波のピーク 周波数 $f_{p}$ に対して示した. 図-8でみられた間欠的な レイノルズ応力の負の大きな值の周期と良好な一致 をみせており，今回用いた 4 象限区分法が風波の組 織構造の定量化に適していることがわかる。また, バースト周期が風波のピーク周波数と一意の関係を 持っていることがわかる. 本研究での $f_{p}$ と $T_{B}$ の相関 は以下のようになった。

$$
T_{B} \propto f_{p}^{0.68}
$$

\section{5. 結論}

本研究はレーザ流速計と波高計の同時計測によっ て水側の平均流特性, また4象限区分しきい値法を用 いることによってその組織構造を検討した．得られ た結果は以下のようになる。

(1) 水面に波が発生した際の水側の乱流強度は，風 波のパラメータである水面変動強度 $\eta^{\prime}$ と風波のピー ク周波数 $f_{p}$ 用いて無次元化すると一つに表すことが できる。

(2) 本研究で上記の特性が成立する領域 (DBBL) の 深さは平均主流速の正負に関わらず，有義波高の3-7 倍で, 從来の結果と一致した。 また, この範甩の乱 れ強度比が約1.0であったことから，この領域での乱 れの等方性が確認された。

(3) 4象限区分しきい值法による条件付きサンプリ ングによって求めたバーストの周期と, レイノルズ 応力の時系列でみられた間欠的な負の大きな值の発 生する周期が良好に一致した。 また，この周期は風 波のピーク周波数と一意の関係を持つことがわかっ た。

(4) 界面近傍での水面から下方に突っ込むバースト の周期の特性を明らかにすることは, 気層から水層 への運動量・気体の輸送を予測する上で重要であ る. 本研究の結果によって, 風波発生下の流れにお けるバーストの周期を風波のピーク周波数によって 予測できることが示唆された。

\section{参考文献}

1)Okuda, K. : Internal flow structure of short wind waves. Part I. On the internal vorticitiy structure, J. Oceanogr. Soc. Japan, vol.38, pp.28-42, 1982.

2)Okuda, K. : Internal flow structure of short wind waves. Part II. The streamline pattern, J. Oceanogr. Soc. Japan, vol.38, pp.331-338, 1982.

3)Okuda, K. : The structure of the boundary layer under wind waves, In "Ocean Surface." ed. by Toba, Y., Mitsuysu, H. and Reidel, D., pp.407-412, 1985.

4)霹津家久, 中山忠暢 : 風波発生下での空気層及び水層 における瞬間構造に関する研究, 水工学会論文集, vol. 44, pp.897-902, 2000.

5)Yoshikawa, I., Kawamura, H., Okuda, K. and Toba, Y. : Turbulent structure in water under laboratory wind wave, J. Oceanogr. Soc. Japan, vol.44, pp.143-156, 1988.

6)Toba, Y. : Wind-wave coupled downward-bursting boundary layer (DBBL) beneath the sea surface, J. Oceanogr. Soc. Japan, vol.52, pp.409-419, 1996.

7)Toba, Y. : Similarity laws of the wind wave and the coupling process of the air and water turbulent boundary layers, Fluid Dyn. Res., vol.2 , pp.263-279, 1988.

8)Komori, S., Nagaosa, R. and Murakami, Y. : Turbulence structure and mass transfer across a sheared air-water interface in wind-driven turbulence, J. Fluid Mech., vol.249, pp.161-183, 1993.

9)Danckwerts, P. V. : Significance of liquid-film coefficients in gas absorption, Indust.\& Eng. Chem., vol.43, No.16, pp.1460-1467, 1951.

10)Rashidi, M. and Banerjee, S. : The effect of boundary conditions and shear rate on streak formation and breakdown in turbulent channel flows, Phys. Fluids., A, vol.2, pp.1827-1838, 1990.

11)Rashidi, M., Hetsront, G. and Banerjee, S. : Mechanism of heat and mass transport at gas -liquid interfaces, Intl $\mathrm{J}$. Heat Mass Transfer, vol.34, pp.1799-1810, 1991.

12)Hunt, J. C. R. and Graham, J. M. R. : Free-stream turbulence near plane boundaries, J. Fluid Mech., vol.84, pp.209-235, 1978.

13)Nezu, I. and Nakagawa, H. : Turbulence in Open-Channel Flows, IAHR-Monograph., Balkema, 1993.

(2000. 10. 2受付) 